\title{
The Role and Performance of Sustainable Microfinance Institutions (MFIs)
}

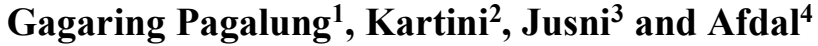 \\ ${ }^{1}$ Hasanuddin University, Indonesia \\ ${ }^{2}$ Hasanuddin University, Indonesia \\ ${ }^{3}$ Hasanuddin University, Indonesia \\ ${ }^{4}$ Hasanuddin University, Indonesia
}

\begin{abstract}
Microfinance is a new financial instrument tool in the development of poverty alleviation and equity and or income generation of low-income people. Microfinance is function as a macro financial development stimulus that will ultimately affect national economic growth. The purpose of this research is to identify and map the problems of microfinance in microfinance institutions (MFIs) and the achievement of their performance so that they can be a stimulus for the development of microfinance businesses. The results of the identification and mapping of microfinance problems in these MFIs will result in a "new model of sustainable microfinance institutions". The sustainable microfinance model will have an impact on poverty alleviation solutions and income distribution. Sharia-based microfinance institutions (Bank Waqaf) show a better success rate of funding turnover than conventional microfinance institutions. Sharia-based microfinance institutions have superior SOPs and governance by instilling religious values and more rigorous and effective management performance.
\end{abstract}

Keywords: microfinance (micro finance), financial microfinance institutions, microfinance management models, poverty alleviation.

\section{Introduction}

The problem of poverty is a socio-economic problem faced by every country, especially developing countries like Indonesia. To overcome this problem a 'financial instrument' has been developed which is expected to reduce and overcome poverty, namely the development of microfinance (World Bank Group) (2015), Khavul (2010), Sengupta and Aubuchom (2008), (Cull, Kunt, and Morduch (2009). Indonesia as a developing country with a population that ranks fourth in the world faces the problem of poverty and income equality which has created an increasingly high gap. Efforts that have been made by the government with various programs and activities in alleviating poverty have been widely carried out, but it has not been solved and even leads to an increase in the gap in income distribution even higher.

One financial instrument that can be done in reducing poverty is the development of microfinance, which in Indonesia is better known as the development of MSMEs (Micro, Small and Medium Enterprises). Definition of microfinance which is intended to focus more on micro-enterprises with low-income specifications with business turnover of less than Rp.50,000,000 and individual businesses. The development of microfinance is more focused on developing financial inclusion that has access to small individuals / businesses that are not touched by banking. The successful and rapidly developing model of microfinance development is the model for the development of Grameen Bank's microfinance which was pioneered and the 2006 Nobel prize winner Muhammad Yunus in Bangladesh. Muhammad Yunus has successfully implemented a model for developing a microfinance institution (micro finance institute) so as to overcome poverty in his area. One of the keys to the success of Grameen Bank's success in helping known as "Grameen credit" is not only based on collateral or contracts but based on "trust or trust". (Sengupta and Aubuchon (2008).

The direction of this research is to develop a 'microfinance model' which is expected to help micro individuals / businesses in the future so that they can be expected to be more independent and become micro entrepreneurs who have a business sustainability and competitive concept. Therefore, the main 
focus of this research is to find out the main problems faced by Microfinance Institutions (MFIs) in the provinces of South and West Sulawesi, then further mapped the problem to make a problem solving in the form of a 'microfinance development model' which later its success can be implemented and measured as an alternative microfinance development model.

In addition, the content specifies the values of local wisdom inherent in Indonesians and the geographical location of the provinces of South and West Sulawesi which are inherent in the values of local wisdom such as sipatuo-sipatokkong (mutual help), sipakainge-sipuk or (remind each other of kindness and mutual respect respect) are the values of Bugis Makassar's local wisdom. Based on the background above, a research question was formulated "How is the problem of microfinance institutions faced in channeling microfinance to individuals and or group customers". Besides that, a culture-based microfinance management model and local wisdom will develop in South and West Sulawesi.

The objectives of this research are (1) to find out the problems and solutions of microfinance in the MFIs faced in channeling microfinance to individuals and or group customers, and (2) produce a 'microfinance management model' based on culture and local wisdom that develops in Sulawesi Selatan.

This research was conducted to obtain a comprehensive picture of the conditions and problems faced by MFIs and individual borrowers or individual micro businesses and / or micro business groups that are developing in the community in the provinces of South Sulawesi. There are hundreds of MFIs and thousands of individuals and / or micro businesses that interact and utilize microfinance transactions such as loans, credit, savings, and microfinance services transactions. The formulation of a new microfinance development model resulting from this study in multiyear will be expected to contribute to the development of a microfinance model that can be implemented nationally. To produce a microfinance model, as expressed by Sengupta and Aubuchon (2008), a long-time implementation is needed.

Some economic studies of inclusion - microfinance - have been carried out in several countries in an effort to alleviate poverty, income distribution, economic growth and others have been carried out both partially and comprehensively, showing that microfinance as a tool to solve problems as explained in several studies. (World Bank Group (2015); Khavul (2010); Sengupta and Aubuchom (2008); (Cull, Kunt, and Morduch (2009); Morduck (2002); Lonborgh and Rasmussen (2013); Phan; Nawai and Moh Syarif (2012); McHghock, Biosca and Donaldson (2017); Awaworyi (2014); Modi, Patel, and Patel (2014); Brau and Woller (2004); Copestake (2010); and Barr (2004).

World Bank (world Bank Group, 2015) has published a field survey research report that shows microfinance with financial inclusion as an access to financial services for non-banks, access to microfinance management and financial services with geographic and socioeconomic dimensions, microfinance will serve services for households and micro-enterprises which has an impact on finance, social, and the environment.

Khavul (2010) revealed the role of microfinance as a new alternative way to develop and stimulate economic growth in developing countries. The purpose of this study is to identify microfinance problems o and possibilities for future research related to areas of economic growth. The study examines the microfinance revolution in every model of microfinance management and developed innovation, especially in the Grameen Bank microfinance pioneered by Muhammad Yunus. Besides that, it was also revealed micro-economic development practices in various countries such as Bangladesh with its Grameen Bank, Banco Sol in Bolivia, Compartamos in Mexico, and Enterprises Development Group in Washington D.C USA (Sengupta and Aubuchon, 2008).

Other microfinance studies that examine the choice of microfinance combination results from the perspective of customers and microfinance institutions can be the perspective of agencies and contracts and regulations that are in the development of microfinance (Cull, Kunt, and Morduch, 2009). Overall the microfinance model is a tool or financial instrument that stimulates economic development and has an impact on poverty reduction and income distribution. Research Methods 
This study was designed as a field research to obtain and identify the main problems of existing microfinance management models in microfinance institutions that have been running. in the provinces of South and West Sulawesi. The research was carried out through field survey research on individual and group objects studied, then conducted mapping and analysis of microfinance management problems carried out by OKKM and individual borrowers and / or groups that have loans, then a microfinance management model will be developed which will be implemented in a sample of microfinance institutions.

In detail the stages of this research are carried out with the following stages:

1. The first stage is the identification and information stage of Micro Finance Institutions operating in South and West Sulawesi Provinces through data in the Financial Services Authority (OJK)

2. After obtaining preliminary data from OJK, then scheduling visits to the area or to the field where the MFI operates in South and West Sulawesi Provinces

3. Make visits and discuss with existing MFIs with the aim of identifying problems and models implemented by each MFI; and

4. Develop a model for developing microfinance based on local wisdom and / or alternative development models.

The object of this research is all the MFI that operated in South Sulawesi. As a comparison of the application of MFI, the MFI implementation survey was originally included in the area of South Sulawesi Province, namely Polewali Mandar District (Polman) which developed in the area. Thus, the object of this study was conducted on all MFIs operating in the provinces of South Sulawesi and West Sulawesi. Based on the characteristics of the study, the analysis of the research was carried out by analyzing in depth the results of the interviews, the data and information obtained for further descriptive and qualitative analysis. Furthermore, mapping and solving microfinance problems and the results of mapping and solving microfinance problems are then made a research report. The results of the study from an in-depth study of the analysis and mapping of microfinance problems are then used as a first step to create a new model as an alternative model of microfinance management in MFIs.

\section{Research Methodology}

This research uses a descriptive method. This research uses secondary data.

\section{Result and Discussion}

MFI is a business activity that includes business development through loans or financing in microscale business to members and the community, savings management, as well as the provision of business development consulting services. This definition is based on the definition of OJK Regulation Number 62 / POJK.05 / 2015 as amended by the previous regulation Number 13 / POJK.05 / 2014 and as mandated in the Law of the Republic of Indonesia Number 1 of 2013 concerning Microfinance Institutions. MFIs consist of two types, namely Conventional MFI and Sharia MFI. In Act No. 1 of 2013 the MFI is defined as a financial institution specifically established to provide business development services and community empowerment, either through loans or financing in micro-scale businesses to members and communities, savings management, as well as providing business development consulting services that are not solely looking for profit.

The MFI aims to (a) improve access to micro-scale funding for the community; (b) help increase economic empowerment and community productivity; and (c) help increase the income and welfare of the community, especially the poor and / or low-income people. Based on the understanding and purpose of MFIs, then MFIs are chosen which have been operating based on the OJK regulations and the Act above.

The existing MFIs in the provinces of South Sulawesi and West Sulawesi are as follows:

1. Aisyiah Islamic Boarding School Waqf LKM "Ummul Mukminin"

2. LKM Bunga Padi Gapoktan 
3. LKM of Tanah Bahagia Gapoktan

4. LKM Gapoktan Sumber Makmur

5. LKM Gapoktan Reski Tunas Semi

6. Karya Tani Gapoktan LKM

7. Assama Lebuang Gapoktan LKM

8. LKM Gapoktan Mataram

The eight MFIs above have pocketed operational licenses and have operated based on the OJK Regulation which regulates the organization of MFI business activities. Management of Islamic Boarding School Waqf Islamic Boarding School Aisyiah "Shariah-based Community Trustee" located in Biringkanaya District, Makassar City, while seven other MFIs are conventionally located in Polewali Mandar District. LKM Bank Wakaf Pesantren Aisyiah which was launched by President Joko Widodo in early 2018 as one of the Waqf Banks of the first 20 Waqf Banks in Indonesia. LKM Ummul Mukminin is the only MFI operating in Makassar LKM Ummul Mukminin is located in Biringkanaya Subdistrict, Makassar City which has 5 groups called halmi (weekly halaqah) which each halmi group has members of 10 to 25 people and overall membership up to currently 70 people. The following is the name of the weekly halaqah group (halmi) and the number of members:

Table 1. Ummul Mukminin's members

\begin{tabular}{|l|l|c|}
\hline No & Name of Halmi & Number of Member \\
\hline 1 & Anugrah & 10 \\
\hline 2 & Reski & 10 \\
\hline 3 & Sakinah & 25 \\
\hline 4 & Amanah & 15 \\
\hline 5 & Berkah & 10 \\
\hline & Jumlah & 70 \\
\hline
\end{tabular}

LKM Ummul Mukminin operates around the area of the Putri Islamic Boarding School located in Biringkanaya Subdistrict with an operating area and recruitment membership around a radius of $5 \mathrm{~km}$ around the pesantren. The recruitment pattern of members is carried out by the board of MFIs with the first around the pesantren with the target of the prosperous community who have a business and after getting enough prospective members who are interested in being involved in the MFI, there will be a meeting of prospective members and socialization of MFI understanding and activities. After gaining an understanding and willing to follow the rules of the rules that have been determined by the MFI and guided by the operations of MFIs in sharia and OJK, the board will make visits to the homes and businesses of prospective recipients to see the conditions of the prospective and living houses of the candidates, including administrators conducting interviews with prospective neighbors to ensure that candidates need MFI fund financing assistance. Then a meeting of prospective members will be held to form groups and name the group.

After being formed, discussions with group members were held and appointed group leaders, then socialization of the members in a group and after getting the socialization then a question and answer session was conducted to explore the purpose of the MFI. After the socialization succeeded, the process of reading and signing of the pledge as a member of the MFI was carried out to be carried out properly because essentially the MFI members received financial assistance as a mandate to be carried out collectively because if there was one member in arrears, the group leader and or the members will bear a lot of the members' arrears. As a whole the activities of the MFIs of the Mumineen Community are developing and running smoothly and the rate of return and turnover of loan funds that runs in each group runs $100 \%$. This result shows that the success rate of sharia-based MFI operations can be said to be very successful and the prospect of waqf bank activities can be said to run smoothly and successfully. 
Conventional MFI. There are 7 (seven) conventional MFIs studied and all conventional MFIs in agricultural clusters. Conventional MFI is a Cooperative model in agriculture and is a funding assistance from the government program in 2009 which was named PUAP Program, namely the Agricultural Agribusiness Leading Program. The following is the name of the MFI studied by visiting each MFI and conducting in-depth discussions related to the profile and the condition and performance of the MFI itself.

Tabel 2. Local MFIs

\begin{tabular}{|l|l|l|l|}
\hline No & \multicolumn{1}{|c|}{ MFI } & \multicolumn{1}{|c|}{ Location } & \multicolumn{1}{c|}{ Leader } \\
\hline 1 & Gapoktan Bunga Padi & Desa Mapilli Barat Kecamatan Luyo & Burhan \\
\hline 2 & Gapoktan Assama Lebuang & Desa Rumpa, Keamatan Mapilli & Abd. Rahim \\
\hline 3 & Gapoktan Mataram & Desa Botto Kecamatan Campalagian & Abd Fattah \\
\hline 4 & Gapoktan Sumber Makmur & Desa Kebunsari Kecamatan Wonomulyo & Sumpono \\
\hline 5 & Gapoktan Tanah Bahagia & Desa Sidurejo Kecamatan Wonomulyo & Ardin \\
\hline 6 & Gapoktan Karya Tani & Desa Pussui Barat Kecamatan Luyo & - \\
\hline 7 & Gapoktan Reski Tunas Semi & Desa Banato Rejo Kecamatan Tapango & Abd. Hakim \\
\hline
\end{tabular}

This conventional microfinance judge is a financial institution in the form of a cooperative with its operation has been going on for a long time and the initial capital in this conventional MFI is a fund from the government by obtaining funds amounting to Rp. 100,000,000 (one hundred million) per cooperative which is an Agricultural Agribusiness Business Program (PUAP) from the Ministry of Agriculture in 2009. In 2015 the comparative institution changed its function to a Microfinance Institution based on government regulations namely OJK number 62 in 2015 so that most of the cooperative institutions must adjust based on OJK rules, not based on the rules of the Ministry of Cooperatives and MSMEs and the Ministry Agriculture. For the Polewali Mandar area, only seven cooperatives that have obtained permit approval operate in the form of Microfinance Institutions as described above.

Tabel 3. Local MFI's performance

\begin{tabular}{|l|l|c|c|}
\hline No & \multicolumn{1}{|c|}{ MFI } & Member & Performance \\
\hline 1 & Gapoktan Bunga Padi & 5 & 180.000 .000 \\
\hline 2 & Gapoktan Assama Lebuang & 7 & 160.000 .000 \\
\hline 3 & Gapoktan Mataram & 24 & 170.000 .000 \\
\hline 4 & Gapoktan Sumber Makmur & 17 & 146.000 .000 \\
\hline 5 & Gapoktan Tanah Bahagia & 14 & 125.000 .000 \\
\hline 6 & Gapoktan Reski Tunas Semi & 4 & 115.000 .000 \\
\hline
\end{tabular}

Each MFI has a varied group and each group consists of 25 farmers. PUAP assistance turnover results of Rp.100,000,000, - for 9 years (PUAP assistance in 2009) has generated funds that exceed the initial capital, however, there are several groups that are still delayed payments, especially in the Land Bahagia LKM, and Sumber Makmur LKM . From the success of the perspectives of the success of MFIs, the Rice MFIs that have the best performance compared to other MFIs are able to mobilize their members well so that arrears are minimal. In addition, several awards were obtained from the government from the regional level to the central level, including the 2015 national best Gapoktan award from the President of the Republic of Indonesia.

\section{Conclusion}

Based on the results of the study of two types of MFIs, each type of MFI has its own characteristics because its members are different types of businesses. LKM Ummul Mukminin with the characteristics of membership of micro-businesses with a religious / sharia approach results in a 
revolving fund refund rate of $100 \%$ so that there are no arrears. This is because the management of its members is more stringent by implementing the "Halmi" (weekly Halaqah) program in the form of studies of religious studies and social concerns which result in the establishment of close relationships with each other. Unlike the case with Gapoktan LKM whose members are all rice farmers with different levels of need for each farmer due to different ownership of paddy fields and average revolving fund returns of around $90 \%$. This means that there are only members who harvest the rice fields still delinquent payments. In some MFIs there are even more than $10 \%$ in arrears, namely the Tanah Bahagia LKM and Sumber Makmur LKM.

\section{References}

Cull Robert, Kunt Asli Demirgu, Morduch Jonathan, 2009, Microfinance Tradeoffs: Regulation, Competition, and Financing, Policy Research Working Paper 5086, The World Bank

Khavul Susanna, 2010, Microfinance: Creating Opportunities for the Poor?, The Academy and Management, University of Texas

Sengupta Rajdeep dan Aubuchon Craig P. 2008, The Microfinance Revolution: An Overview, Federal Reserve Bank of St. Louis Review

IEG World Bank Group, 2015, Microfinance: A Critical Literatur Survey, Working Paper No.4, World Bank Group

Jonathan Morduch dan Barbara Haley, 2002, Analysis of the Effect of Microfinance on Poverty Reduction, Warking Paper Series, NYU Wagner

Norhaziah Nawai dan Mohd noor Mohd Shariff, 2012, Factors affecting repayment performance in Microfinance in Malaysia, Procedia Social and Behavioral Sciences

McHugh Neil, Olga Biosca dan Cam Donaldson (2017) From Wealth to Health: Evaluating Microfinance as a Complex Intervention, Sage Jounals

Sefa K. Awaworyi (2014) Impact of Microfinance Intervention: A Meta-Analysis, Riset Paper 03, Monash University

Ashwin G. Modi, Kira J Patel dan Kunda M. Patel, 2014, Impact of Microfinance Service on Rural Women Empowerment: An Empirical Study, Journal of Business and Management

James c Bran dan Gary m. Woller, Spring 2014, Microfinance: A Comprehensive Review of the Existing Litereture, The Journal of Enterpreneurial Finance

Michael S. Barr (2004) Microfinance and Financial Development, University of Michigan Law School

The World Bank, The New Microfinance Handbook: A Financial Market System Perspective

Niels Hermes dan Robert Lensink, 2007, The Empirics of Microfinance: What Do We Know, The Economic Journal, Blackwell Publishing 